\title{
DETERMINANTS OF PROFIT EFFCIENCY AMONG PEANUT FARMING HOUSEHOLDS IN TRA VINH PROVINCE, VIETNAM
}

\author{
NGUYEN HUU DANG \\ Can Tho University, Vietnam - nhdang@ctu.edu.vn
}

(Received: March 23, 2017; Revised: July 19, 2017; Accepted: July 25, 2017)

\begin{abstract}
This study is aiming to identify profit efficiency and its determinants among peanut farming households in Tra Vinh province, Vietnam, based on the data collected from 182 peanut farming households in three districts of Tra Vinh province. The Cobb-Douglas stochastic frontier profit function incorporating profit inefficiency effects was employed to analyze the data, using the Frontier 4.1. The results revealed that the profit efficiency was ranged between 29.80 to 96.76 percent, average of 59.06 percent. Significant factors that were found negative affect the peanut farm profit were prices of fertilizer, pesticide, wage rate; whereas, price of seed and land area (fixed factor) were found negative effect the peanut farm profit. Significant determinants that were found positive affect profit efficiency of peanut farmers were gender, education attainment, peanut farming experience, farm size, credit access, training, and farmer's association membership.
\end{abstract}

Keywords: Determinant of profit efficiency; Peanut farms; Profit efficiency; Stochastic frontier profit function.

\section{Introduction}

Peanut production in the Mekong River Delta is mostly concentrated in two provinces, namely Long An and Tra Vinh, in which Tra Vinh accounts for 40.03 percent of the region in terms of production area. Tra Vinh is considered as an advantageous province in peanut production in the region in terms of peanut yield. On average, peanut yield in Tra Vinh in 2015 was 5.13 tons/ha while the average peanut yield of the region was 3.95 tons/ha. The peanut yield in Tra Vinh increased twice during period 2001-2010 and by 18 percent during period 2011-2015.

Peanut cultivation is the most important subsector of Tra Vinh since it plays a crucial role in employment creation, income generation, especially from poverty reduction in the rural area. However, it is difficult to expand peanut production by increasing peanut land area or crop intensification since almost all the agricultural land has been utilized. There are also limitations related to crop intensification such as soil erosion, pest infestation, and other issues concerning sustainable development in agriculture. Especially, peanut price always fluctuates over time to the extent that the government does not effectively control. Therefore, promoting policies aimed at sustainable growth in peanut yield and price will be the basis for sustainable development in the peanut subsector in Tra Vinh in the future.

Recently, peanut production in Tra Vinh has been confronted with problems such as the rapid increase in labor cost and other material input costs, which in turn, caused the decrease in the farmers' levels of input use. A reduction in input use may have negative impacts on peanut yield and the productive efficiency of peanut farmers as well. These lead to questions that how are the profit and profit efficiency of peanut farms and what factors affect farm's profit and profit efficiency among the peanut farming households. Thus, this study aims to identify profit efficiency and determinants of profit efficiency among the peanut farming households in Tra Vinh province.

\section{Methodology}




\subsection{Stochastic frontier profit function}

This study adopted the models developed by Battesse and Coelli (1995) and Abdulai and Huffman (1998) by postulating a profit function, which is assumed to behave in a manner consistent with the stochastic frontier framework. Consider a firm that maximizes profits subject to perfectly competitive input and output markets and a single output technology that is quasiconcave in the ( $\mathrm{n} x \mathrm{1})$ vector of variable inputs, $X$, and the $(\mathrm{m} \times 1)$ vector of fixed factors, $Z$. The actual normalized profit function can be expressed as:

$$
\pi(p, F)=Y\left(X^{*}, F\right)-\Sigma p_{i} X_{i}^{*}
$$

where:

$\mathrm{Y}\left(\mathrm{X}^{*}, \mathrm{~F}\right)$ is production function; the asterisk denotes optimized values.

$p_{i}$ is the normalized price of input $i, p_{i}=$ $P_{x} / P_{y}$, where $P_{x}$ and $P_{y}$ are prices of inputs and output, respectively.

The stochastic normalized profit function can then be expressed as:

$$
\pi_{i}=f\left(p_{\mathrm{ji}}, F_{j i}\right) \exp \left(V_{i}-U_{i}\right)
$$

where:

$\pi_{i}$ is normalized profit of the $i^{\text {th }}$ farm, computed as gross revenue less variable cost, divided by farm specific output price $\mathrm{P}_{\mathrm{y}}$;

$\mathrm{p}_{\mathrm{ji}}$ is the normalized price of input $\mathrm{j}$ for the $\mathrm{i}^{\text {th }}$ farm, calculated as input price divided by farm specific output price $\mathrm{P}_{\mathrm{y}}$;

$F_{j i}$ is the level of the $j^{\text {th }}$ fixed factor for the $i^{\text {th }}$ farm

$\mathrm{V}_{\mathrm{i}}$ is the symmetric error term and $\mathrm{U}_{\mathrm{i}}$ is a one - sided error term. $v_{i}$ is normally independently and identically distributed as $N\left(0, \delta_{u}^{2}\right)$ two - sided error term representing various random shocks and effects of measurement error of variables. The $U_{i}$ is the non - negative or one - sided residual representing farm - specific profit inefficiency. Hence if $\mathrm{U}_{\mathrm{i}}=0$, the farm's profit inefficiency is nonexistent, i.e., the farm makes maximum possible profit (being on the frontier) given its input prices and fixed factors. Conversely, $\mathrm{U}_{\mathrm{i}}$
$>0$ indicates that the farm forgoes profit due to inefficiency (Ali and Flinn, 1989).

The profit efficiency index (PE) in relation to the stochastic profit frontier is given by

$$
\begin{aligned}
P E= & U_{i}=\frac{\pi_{i}}{\pi_{i}^{*}}=\frac{f\left(p_{j i}, F_{j i}\right) \exp \left(V_{i}-U_{i}\right)}{f\left(p_{j i}, F_{j i}\right) \exp \left(V_{i}\right)}=\exp \left(-U_{i}\right) \\
& \pi_{i} \text { is an observed profit and } \pi_{\mathrm{i}}^{*} \text { is the }
\end{aligned}
$$
frontier profit. The $\mathrm{p}_{\mathrm{ji}}, \mathrm{F}_{\mathrm{ji}}, \mathrm{U}_{\mathrm{i}}$ and $V_{i}$ have been defined earlier. In this case, $\pi_{\mathrm{i}}$ achieves its maximum value of $f\left(p_{\mathrm{ji}}, F_{j i}\right) \exp \left(V_{i}\right)$ if and only if $\mathrm{PE}_{\mathrm{i}}=1$. Otherwise, $\mathrm{PE}_{\mathrm{i}}<1$ provides a measure of the shortfall of observed profit from maximum feasible profit.

The profit inefficiency index (PIE) is therefore hypothesized to be related to attributes of the farming households as following:

$$
P I E=1-\exp \left(-U_{i}\right)
$$

Profit loss due to inefficiency is represented as potential maximum profit given farm - specific prices and fixed factors, multiplied by farm - specific profit inefficiency index.

The stochastic profit frontier model as shown in equation 2 could be estimated using maximum likelihood method, which is asymptotically more efficient than the other alternative (Battese and Coelli, 1995). Mean profit efficiency (industry profit efficiency) could be easily predicted using the mathematical expectation of individual profit efficiency. A natural predictor of mean profit efficiency would be the arithmetic mean of the farm specific efficiencies in the samples.

\subsection{The Empirical Model}

Several studies (e.g. Battesse and Safraz, 1998; Kolawole, 2006) used the CobbDouglas functional form to estimate the profit function for different commodities. For this study, the Cobb-Douglas functional form was also used to estimate the stochastic profit function. The specific farm profit function is expressed as follows: 


$$
\ln \pi_{i}=\beta_{0}+\sum_{j=1}^{5} \beta_{j} \ln P_{j i}+\beta_{6} \ln F_{6 i}+V_{i}-U_{i}
$$

Where: $\beta_{0}$ : intercept; $\beta_{\mathrm{j}}$ and $\beta_{6}$ : regression coefficients of the explanatory variables in the estimated stochastic profit function, where $\mathrm{j}=$ $1,2 \ldots 5 ; \pi_{\mathrm{i}}$ : restricted normalized profit computed for $j$ th farm defined as gross revenue less variable costs per farm divided by farm specific peanut price $\left(\mathrm{P}_{\mathrm{y}}\right) ; \mathrm{P}_{j i}$ : prices of variable inputs contributing to profit of farmers where (for $i=1,2 \ldots 5$ ), consisting of: $\mathrm{P}_{1 \mathrm{i}}$ : price of seed $(\mathrm{VND} / \mathrm{kg})$ normalized by price of output $\left(\mathrm{P}_{\mathrm{y}}\right) ; \mathrm{P}_{2 \mathrm{i}}$ : weighted average price of fertilizer $(\mathrm{VND} / \mathrm{kg})$ normalized by price of output $\left(\mathrm{P}_{\mathrm{y}}\right) ; \mathrm{P}_{3 \mathrm{i}}$ : weighted average price of chemical pesticide (VND/liter) normalized by price of output $\left(\mathrm{P}_{\mathrm{y}}\right) ; \mathrm{P}_{4 \mathrm{i}}$ : Price of labor (VND/man-day) normalized by price of output $\left(\mathrm{P}_{\mathrm{y}}\right)$; and $\mathrm{P}_{5 \mathrm{i}}$ : price of tractor service (VND/hectare) normalized by price of output $\left(\mathrm{P}_{\mathrm{y}}\right) . \mathrm{F}_{6 \mathrm{i}}$ : land area (ha/farm); $\mathrm{V}_{\mathrm{it}}$ : random variable assumed to be independently and identically distributed (iid) $\mathrm{N}\left(0, \sigma_{\mathrm{v}}{ }^{2}\right)$ and independent of $\mathrm{U}_{\mathrm{i}}$; $\mathrm{U}_{\mathrm{i}}$ : non-negative random variable that is assumed to account for profit inefficiency in peanut production; $\ln$ : natural logarithm; $\mathrm{i}=1 \ldots \mathrm{N}, \mathrm{N}$ : number of observations; and the subscripts $j, i$ refer to the $\mathrm{j}^{\text {th }}$ input used of $\mathrm{i}^{\text {th }}$ farm.

The peanut farm level profit inefficiency (PIE) model was simultaneously estimated with the stochastic frontier profit function. The PIE model for the peanut farm is expressed mathematically as follows:

$$
P I E_{i}=U_{i}=\delta_{0}+\sum_{j=1}^{9} \delta_{j} Z_{j i}+\xi_{i}
$$

Where: $\delta_{0}$ : intercept; $\delta_{\mathrm{j}}$ : regression coefficients of the explanatory variables in the estimated profit inefficiency model, where $\mathrm{j}$ : $1,2 \ldots 9 ; \mathrm{Z}_{\mathrm{ji}}$ : factors contributing to profit inefficiency such as: $Z_{1 \mathrm{i}}$ : gender of farmer dummy (male: 1 ; female: 0 ); $\mathrm{Z}_{2 \mathrm{i}}$ : educational attainment of the farmer (years of schooling); $\mathrm{Z}_{3 \mathrm{i}}$ : experience of the farmer in peanut farming (years); $\mathrm{Z}_{4 \mathrm{i}}$ : household members in farming - number of family members engaged in peanut farming (number of persons/ household); $\mathrm{Z}_{5 \mathrm{i}}$ : farm size dummy (area $\geq 0.6$ hectare: 1 ; area $<0.6$ hectare: 0$)$; $\mathrm{Z}_{6 \mathrm{i}}$ : credit access dummy (with credit access: 1 ; no credit access: 0 ); $\mathrm{Z}_{7 \mathrm{i}}$ : attendance in training on peanut production dummy (with training: 1; no training: 0 ); $\mathrm{Z}_{8 \mathrm{i}}$ : membership in a farmers' association dummy (member: 1 ; not member: $0)$; $\mathrm{Z}_{9 \mathrm{i}}$ : distance from the peanut field to the key input market $(\mathrm{km})$; $\xi_{\mathrm{i}}$ : error terms, assumed to be independently and identically distributed with mean: 0 and variance: $\sigma_{\xi}{ }^{2}$; and the subscripts $j, i$ refer to the $\mathrm{j}^{\text {th }}$ characteristic of the $\mathrm{i}^{\text {th }}$ farm.

\subsection{Data}

The data in this study is cross - sectional data collected by directly interviewing 182 peanut farmers in three districts of Tra Vinh province, namely Cau Ngang, Duyen Hai and Tra $\mathrm{Cu}$. About 60 peanut farmers per each district were selected by random sampling. The data collection includes quantity of input use, peanut yield, prices of input use and peanut in the second crop of 2015 and other data related to the peanut farming household's specific characteristics.

\section{Results and Discussion}

\subsection{Peanut farming household's specific characteristics}

On average, the interviewed peanut farmers have 6.10 years of schooling, 7.63 years of peanut farming experience, 0.32 ha of peanut farming area, 2.57 household labors. These indicate that education attainment of the peanut farmers are quite low and the farm size is quite small, which would be logically a somewhat barrier in adaption new production technology. The average distance from the main peanut field to the key input market is $1.97 \mathrm{~km}$, which implies that most of the peanut farmers are living around their peanut fields. There is only 37 percent of interviewed peanut farmers accessed the formal credit 
while another 63 percent were self-financing for their peanut farming; 43 percent of respondents participated in peanut production training while another 57 percent did not join any training related to peanut farming over last three years; and 52 percent of respondents are member of local farmer's association (Table 1).

\section{Table 1}

Peanut farming household's specific characteristics of 182 interviewed peanut farmers in Tra Vinh province, Vietnam

\begin{tabular}{lccc}
\hline Household 's characteristics & Unit & Average & Std. Dev. \\
\hline Gender dummy & 1: male; 0: female & 0.74 & 0.44 \\
Educational attainment & Year & 6.10 & 3.63 \\
Peanut farming experience & Year & 7.63 & 5.19 \\
Household farm labor & Person & 2.57 & 1.01 \\
Farm size dummy & 1: area $\geq 0.6$ hectare; 0: not & 0.32 & 0.47 \\
Credit access dummy & 1: borrowed; 0: not & 0.37 & 0.49 \\
Training dummy & 1: Participated; 0: not & 0.43 & 0.50 \\
Farmer's association membership dummy & 1: member; 0: not & 0.52 & 0.50 \\
$\begin{array}{l}\text { Distance from the main field to the key } \\
\text { input market }\end{array}$ & Km & 1.97 & 1.26 \\
\hline
\end{tabular}

Source: Author's survey in 2016

\subsection{Costs and returns of peanut} production

On average, peanut yield and prices are $6,718.8 \mathrm{~kg} / \mathrm{ha}$ and $10,667.3 \mathrm{VND} / \mathrm{kg}$, respectively, which results in a gross income of 71,604,600 VND ( 3,113.24 USD). With the total costs of production of $53,475,700$ VND/ha, the net income is $18,186,500$ VND/ha ( 790.72 USD). The net income on gross income and total costs ratios are 25.4 percent and 34.0 percent, respectively (Table 1). These profitable ratios are too high in comparison with other industries (i.e. manufacturing, service).

Among cost items, cost of labor occupies the largest share of total costs, around 38.8 percent of total costs, in which cost of hired and family labor account for about 9.8 percent and 29.0 percent of total costs, respectively. The following is the cost of seed, accounting for 17.6 percent of total costs. Thus, costs of labor and seed account for about 56.4 percent of total costs while other 6 cost items account for another $43.6 \%$. 
Table 2

Costs and returns per hectare in peanut production of 182 interviewed peanut farmers in Tra Vinh province, Vietnam

\begin{tabular}{|c|c|c|c|c|}
\hline Item & Unit & Value & Cost structure (\%) & Std. Dev. \\
\hline Gross income & $\mathrm{Kg} / \mathrm{ha}$ & & & \\
\hline Peanut yield & & $6,718.8$ & & 818.4 \\
\hline Average selling price & $\mathrm{VND} / \mathrm{kg}$ & $10,667,3$ & & 7,472 \\
\hline Total gross income (GI) & '000 VND & $71,604.6$ & & $9,623.0$ \\
\hline \multicolumn{5}{|l|}{ Costs } \\
\hline \multicolumn{5}{|l|}{ Cash costs } \\
\hline Land preparation & ‘000 VND & $1,512.9$ & 2.8 & 397.5 \\
\hline Seeds & '000 VND & $9,400.9$ & 17.6 & 2491.4 \\
\hline Fertilizers & '000 VND & $9,049.7$ & 16.9 & 3545.9 \\
\hline Pesticides & ‘000 VND & $2,330.7$ & 4.4 & 1211.0 \\
\hline Hired labor & '000 VND & $5,239.1$ & 9.8 & 1976.8 \\
\hline Harvesting & ‘000 VND & $7,736.1$ & 14.5 & 1401.5 \\
\hline Other costs & ‘000 VND & $2,057.9$ & 3.8 & 1035.0 \\
\hline Sub-total & & $37,327.4$ & & 4797.9 \\
\hline \multicolumn{5}{|l|}{ Non-cash costs } \\
\hline Family labor & '000 VND & $15,505.0$ & 29.0 & 7516.1 \\
\hline Depreciation & ‘000 VND & 643.3 & 1.2 & 595.8 \\
\hline Sub-total & '000 VND & $16,148.3$ & & $7,737.2$ \\
\hline Total costs (TC) & '000 VND & $53,475.7$ & 100.0 & $6,049.3$ \\
\hline Net income (GI-TC) & '000 VND & $18,186.5$ & & $8,669.4$ \\
\hline Net income/gross income $(\%)$ & $\%$ & 25.4 & & 9.1 \\
\hline Net income/Total costs $(\%)$ & $\%$ & 34.0 & & 23.0 \\
\hline
\end{tabular}

Source: Author survey in 2016

3.3. Results of the stochastic frontier profit analysis

In the stochastic Cobb-Douglas frontier profit model, the estimated coefficients of the independent variables are profit elasticities. The profit elasticity shows the percent change in farm profit with respect to a percent change in given variable input price or fixed factor, ceteris paribus. Among the six parameters of input prices and fixed factors included in stochastic frontier profit model, only service track rate had no significant effect on farm profit in peanut production in the study areas (Table 3). 


\section{Table 3}

MLE of the Cobb-Douglas stochastic profit function and profit inefficiency model, 182 interviewed peanut farmers in Tra Vinh province, Vietnam

\begin{tabular}{|c|c|c|c|c|c|c|}
\hline \multirow{2}{*}{\multicolumn{2}{|c|}{$\begin{array}{l}\text { Variable } \\
\text { Symbol Variable name } \\
\text { Frontier profit function }\end{array}$}} & \multirow{3}{*}{$\begin{array}{c}\begin{array}{c}\text { Para- } \\
\text { meters }\end{array} \\
\beta_{0}\end{array}$} & \multicolumn{2}{|c|}{ Coefficient } & \multirow[t]{2}{*}{$\begin{array}{l}\text { Std. } \\
\text { Error }\end{array}$} & \multirow[t]{2}{*}{ t-ratio } \\
\hline & & & & & & \\
\hline & Constant & & 12.537 & $* * *$ & 0.436 & 28.740 \\
\hline $\ln$ Ps & Price of seed (vnd/kg) & $\beta_{1}$ & 0.237 & $* * *$ & 0.040 & 5.918 \\
\hline Ln Pf & Price of fertilizer (vnd/kg) & $\beta_{2}$ & -0.798 & $* * *$ & 0.243 & -3.288 \\
\hline $\ln \mathrm{Pp}$ & Price of pesticide (vnd/litter) & $\beta_{3}$ & -0.108 & $* *$ & 0.051 & -2.137 \\
\hline $\ln \mathrm{W}$ & Wage rate (vnd/day) & $\beta_{4}$ & -0.681 & $* *$ & 0.333 & -2.047 \\
\hline $\ln \mathrm{St}$ & Service tractor rate (vnd/ha) & $\beta_{5}$ & -0.146 & ns & 0.096 & -1.528 \\
\hline $\ln \mathrm{L}$ & Land area (hectare) & $\beta_{6}$ & 0.370 & $* * *$ & 0.039 & 9.383 \\
\hline \multicolumn{7}{|c|}{ Profit Inefficiency function } \\
\hline & Constant & $\delta_{0}$ & 1.925 & $* * *$ & 0.384 & 5.012 \\
\hline $\mathrm{Z}_{1}$ & Gender dummy & $\delta_{1}$ & -0.504 & *** & 0.187 & -2.702 \\
\hline $\mathrm{Z}_{2}$ & Educational attainment (years) & $\delta_{2}$ & -0.052 & $* *$ & 0.026 & -2.013 \\
\hline $\mathrm{Z}_{3}$ & Peanut farming experience (years) & $\delta_{3}$ & -0.028 & $*$ & 0.015 & -1.895 \\
\hline $\mathrm{Z}_{4}$ & Household farm labor (persons) & $\delta_{4}$ & -0.109 & ns & 0.086 & -1.261 \\
\hline $\mathrm{Z}_{5}$ & Farm size dummy & $\delta_{5}$ & -0.217 & $* *$ & 0.105 & -2.061 \\
\hline $\mathrm{Z}_{6}$ & Credit access dummy & $\delta_{6}$ & -0.412 & $* *$ & 0.181 & -2.278 \\
\hline $\mathrm{Z}_{7}$ & Training dummy & $\delta_{7}$ & -0.552 & $* * *$ & 0.187 & -2.952 \\
\hline $\mathrm{Z}_{8}$ & Association membership dummy & $\delta_{8}$ & -0.146 & $*$ & 0.085 & -1.716 \\
\hline $\mathrm{Z}_{9}$ & $\begin{array}{l}\text { Distance from the main field to the } \\
\text { key input market }(\mathrm{km})\end{array}$ & $\delta_{9}$ & -0.034 & $\mathrm{~ns}$ & 0.073 & -0.464 \\
\hline \multicolumn{7}{|c|}{ Variance Parameter } \\
\hline$\sigma^{2}$ & & & 0.389 & $* *$ & 0.103 & 3.762 \\
\hline$\gamma$ & & & 0.923 & $* * *$ & 0.014 & 68.230 \\
\hline Log-likel & hood function & & -43.06 & & & \\
\hline LR test o & the one-sided error & & 71,52 & & & \\
\hline Mean pro & it efficiency $(\%)$ & & 59,06 & & & \\
\hline $\mathrm{N}$ & & & 182 & & & \\
\hline
\end{tabular}

Note: $* * * * *$, and $*$ indicate statistically significant at $1 \%, 5 \%$, and $10 \%$ probability level, respectively; and ns denotes insignificant at $10 \%$ probability level.

Source: Author estimates 
The regression coefficients of prices of fertilizer, pesticide, wage rate exhibit negative signs and are statistically significant, which implies that the increases in prices or rate of these inputs would lead to decrease of the farm profit level and vice versa.

Otherwise, the coefficient of seed is found positive sign and is statistically significant at one percent probability level, which means that the higher price of seed, implying the higher quality of seed, leads to the higher profitable than those who use the lower quality of seed with lower price, given assumption price of seed is consistent with its quality, and vice versa. Similarly, the coefficient of land area is also found positive sign and is statistically significant at one percent level, which means that the larger farm gain greater profitable than the smaller one and vice versa. This would attribute to that the larger farms gain more economic scale in terms of costs of production, which leads to more profitable than smaller one.

Determinants of profit efficiency: the average profit efficiency was 59.06 percent, which implies that with the recent level price of inputs and fixed factors, the farmers were able to increase their peanut farming profit by 40.94 percent by improving profit efficiency factors. This is to examine the effects of socio-economic and farm-specific factors on profit efficiency of the interviewed peanut farmers. A negative sign of the regression coefficient of an explanatory variable in the profit inefficiency function (table 3 ) indicates that the variable improves profit efficiency. A positive sign means the opposite. The factors which were found positively affect profit efficiency of the interviewed peanut farmers were gender, education attainment, peanut farming experience, farm size, credit access, training, and association membership dummy. On the other hand, household farm labor and distance from the main field to the key input market were not found statistically significant affect the profit efficiency of the peanut farmers.

Educational attainment. Education exhibits a significant effect on profit efficiency. The regression coefficient of the educational attainment of the interviewed farmers is negative and statistically significant at five percent probability level. The negative coefficient means that as the farmer's educational level increases, the profit inefficiency of the farmer decreases. In other words, this implies that the better educated farmers have higher profit efficiency than those with lower educational attainment. This could be explained by the fact that the better educated farmers have better access to information on input and output prices as well as other economic and technical information, which helps them in making better farm management decisions as compared to less educated farmers.

Farming experience. The regression coefficient of the farmer's length of experience in peanut farming is negative and statistically significant at ten percent probability level. This indicates that the more peanut farming experience the farmer has, the higher the level of profit efficiency. This can be attributed to that with more peanut farming experience, the farmers have better production technology, better access to input, output prices, which makes them gain more profit efficiency than less experience farmers.

Farm size. Farm size has a negative regression coefficient and is statistically significant at five percent probability level. This indicates that farmers with larger farms earn significantly higher profit and operate at significantly higher level of profit efficiency than those operating smaller farms. This is logical since those operating large farms frequently purchase material inputs in bulk or in larger volume to get price discounts and in turn lower their input procurement cost. Selling a larger volume of their produce also enables them to bargain for a higher price for their product and minimize marketing/ transportation cost as well.

Farmers' participation in training programs on peanut production and credit access. The participation in training dummy programs for farmers, and credit accesses 
have negative signs and they are statistically significant at one and five percent probability levels, respectively. This suggests that the farmers who participated in training programs on improved peanut farming technologies and practices have higher levels of profit efficiency than those who did not participate in such training programs. In addition, the farmers who were able to gain access to the formal credit have higher profit efficiency than others. This can be attributed to the fact that the farmers who could access to the formal credit have cash available for purchasing production inputs in cash and get better prices of input that bring them more profit and profit efficiency than others.

Membership in farmers' association. The regression coefficient of the dummy farmer variable for membership in a farmers' association has a negative sign and is statistically significant at five percent probability level. This indicates that the farmers who are members of a farmers' association receive higher profits and have higher levels of profit efficiency than non- members. This could be attributed to the fact that the members of a farmers' association have better access to support services like extension and training. Members of a farmers' association may also benefit from selling their produce through their association than selling individually since their association can bargain for a higher price. This result corroborates with the findings of Ali and Flinn (1989) who reported that farmers in remote villages were less profit efficient, even when other factors were taken into account.

Distribution of technical efficiencies: The predicted profit efficiencies of the sample peanut farmer - respondents in Tra Vinh province differed substantially ranging from 29.81 percent to 96.76 percent. About 6.04 percent of the total interviewed farmers belonged to the most efficient category $(90$ $100 \%$ ). Around $22.53 \%$ of the interviewed farmers had profit efficiencies below 50 percent. Majority $(25.27 \%)$ of interviewed peanut farmers belonged to the category (60 $>70 \%$ ), indicating that most of the peanut farmers were very profit efficient (Table 4).

\section{Table 4}

Distribution of profit efficiencies of 182 interviewed peanut farmers in Tra Vinh province, Vietnam

\begin{tabular}{ccr}
\hline Profit efficiency $(\mathrm{PE}, \%)$ & No. of farmers & Percent \\
\hline$<50$ & 41 & 22.51 \\
$50-<60$ & 25 & 13.74 \\
$60-<70$ & 46 & 25.27 \\
$70-<80$ & 39 & 21.43 \\
$80-<90$ & 20 & 10.99 \\
$90-100$ & 11 & 6.04 \\
Total & 182 & 10.00 \\
\hline Average & 59.06 & \\
Minimum & 29,81 & \\
Maximum & 96.76 & \\
Std. Dev. & 21.90 & \\
\hline
\end{tabular}




\section{Conclusions and recommendations}

This study is aiming to identify profit efficiency and determinants of profit efficiency among peanut farmers in Tra Vinh province, Vietnam, based on the data collected from 182 peanut farmers in three districts of Tra Vinh province. The CobbDouglas stochastic frontier profit function incorporating profit inefficiency effects was employed to analyze the data, using the Frontier 4.1. The results revealed that the profit efficiency was ranged between 29.80 to 96.76 percent, average of 59.06 percent, which implies that with the recent level prices of inputs and fixed factors, the peanut farmers were able to increase their peanut farming profit by 40.94 percent by improving profit efficiency factors. Significant factors that were found negatively affect the peanut farm profit were prices of fertilizer, pesticide, wage rate while positive effects were price of seed and land area (fixed factor). Significant determinants that were found positively affect profit efficiency of peanut farmers were gender, education attainment, peanut farming experience, farm size, credit access, training, and association membership dummy.

In order to further improve profit and profit efficiency of peanut production, the study recommends that peanut farmers use high quality varieties; improve fertilizer and pesticide management focusing on efficient use of fertilizer and pesticides; join the farmer's association; and increase the farm size as possible. In addition, the study recommends that local government intensify extension services, particularly the conduct of training programs on peanut production techniques; promote the usage of high quality varieties; promote credit access; strengthen the farmers' association; improve the level of education of farmers through short technical training; and promote the farmers to increase their farm size

\section{References}

Aigner, D., C. Lovell and P. Schmidt (1977). Formulation and estimation of Stochastic Frontier production function models. Journal of Econometrics, 6, 21-37.

Ali, M. and J.C. Flinn (1989). Profit efficiency among Basmati rice producers in Pakistan Punjab. American Journal of Agricultural Economics, 71, 303 - 310.

Abdulai, A. and W. Huffman (1998). An examination of profit inefficiency of rice farmers in Northern Ghana. Staff Paper, 296.

Battese, G. And T. Coelli (1995). A model for technical efficiency effects in a Stochastic Frontier production function for Panel Data. Empirical Economics, 20, 325-332.

Coelli, T., D. Rao, C. O’Donnell and G. Battese (2005). An introduction to efficiency and productivity analysis, Second Edition. United States of America: Springer Science Business Media, Inc, 41-83.

Coelli, T. (2007). Guide to Frontier Version 4.1: A computer program for Stochastic Frontier production and cost function estimation. CEPA Working Paper, 96, 2-6.

Farrell, M.J. (1957). The measurement of productive efficiency. Journal of the Royal Statistical Society, 120, 253-290.

Kolawole, O. (2006). Determinants of profit efficiency among small-scale rice farmers in Nigeria: A profit function approach. Poster paper prepared for presentation at the International Association of Agricultural Economists Conference, Gold Coast, Australia, August 12-18.

Rahman, S. (2003). Profit efficiency among Bangladeshi rice farmers. Food Policy, 28, 487-503.

Tiamiyu, S.A., Akintola, J.O., Rahjim, A.Y. (2010). Production efficiency among growers of new rice for Africa in the Savanna Zone of Nigeria. Agricultural Tropica et Subtropica, 43. 